\title{
ANALISIS FAKTOR YANG MEMENGARUHI KINERJA PENGADAAN BARANG/JASA DALAM KEADAAN DARURAT WABAH COVID-19 DENGAN SOCIAL DISTANCING SEBAGAI VARIABEL MODERATOR
}

\section{ANALYSIS OF FACTORS AFFECTING THE PERFORMANCE OF PROCUREMENT OF GOODS/SERVICES IN THE EMERGENCY OF THE COVID-19 PLAGUE WITH SOCIAL DISTANCING AS MODERATOR VARIABLE}

\author{
Syahirul Alim ${ }^{1)}$, M. Heru Akhmadi2) \\ 1) Pusat Informasi dan Teknologi Keuangan, Kementerian Keuangan, JI Lapangan Banteng Timur 2-4, Jakarta Pusat \\ 2) Politeknik Keuangan Negara STAN, Jl. Bintaro Utama Sektor V, Tangerang Selatan, Banten
}

\section{ARTICLE INFORMATION \\ Article history: \\ Received: September 22, 20 \\ Revised: January 04, 21 \\ Accepted: February 09, 21}

\section{Keywords:}

Procurement performance

Emergency procurement

Procurement regulation

Employee competency

E-procurement

Management commitment

Social distancing

\section{Kata kunci:}

Kinerja pengadaan

Pengadaan darurat

Peraturan pengadaan

E-procurement

Komitmen manajemen

Social distancing

\begin{abstract}
A B S T R A C T
This study analyzes the factors that affect the performance of goods and services procurement in an emergency of the Covid-19 outbreak using social distancing as a moderating variable. The research was conducted at the DKI Jakarta Provincial Government as an organization that already has a good procurement system through questionnaire data. The specific objective of this study is to determine the effect of government regulations on emergency procurement, e-procurement implementation, employee competence, and management commitment to procurement performance during an emergency. The results show that government regulations for emergency situations, employee competence, and implementation of eprocurement have a positive effect on procurement performance in emergency situations of the Covid-19 outbreak. In addition, the research results also show that the social distancing variable does not moderate the influence of the four factors on the performance of the procurement of goods and services. The use of information technology allows communication in completing tasks to be maintained so that the performance of the procurement of goods and services is not disturbed in Covid-19 outbreak.
\end{abstract}

\section{A B S T R A K}

Penelitian ini menganalisis faktor-faktor yang mempengaruhi kinerja pengadaan barang dan jasa dalam keadaan darurat wabah Covid-19 dengan menggunakan social distancing sebagai variabel moderator. Penelitian dilakukan di Pemprov DKI Jakarta sebagai organisasi yang telah memiliki sistem pengadaan yang baik melalui data kuesioner. Tujuan khusus dari penelitian ini adalah untuk mengetahui pengaruh peraturan pemerintah dalam pengadaan darurat, penerapan e-procurement, kompetensi pegawai, dan komitmen manajemen terhadap kinerja pengadaan pada saat keadaan darurat. Hasil penelitian menunjukkan bahwa regulasi pemerintah untuk situasi darurat, kompetensi pegawai, dan implementasi e-procurement berpengaruh positif terhadap kinerja pengadaan dalam situasi darurat wabah Covid-19. Sebagai tambahan, hasil penelitian juga menunjukkan bahwa variabel social distancing tidak memoderasi pengaruh empat faktor terhadap kinerja pengadaan barang dan jasa. Penggunaan teknologi informasi memungkinkan komunikasi dalam penyelesaian tugas tetap terjaga sehingga kinerja pengadaan barang dan jasa tidak terganggu selama pandemic Covid-19.

This is an open access article under the $\underline{\mathrm{CC}-\mathrm{BY}}$ license.

\section{${ }^{\star}$ Corresponding Author: \\ Syahirul Alim}

syahirul@gmail.com

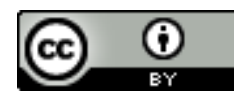

(c) 2021 Some rights reserved 


\section{PENDAHULUAN}

Pengadaan barang/jasa merupakan mekanisme belanja pemerintah yang memegang peranan sangat besar dalam penyerapan anggaran negara. Hal ini disebabkan oleh porsi anggaran pengadaaan barang/jasa yang sangat besar di dalam Anggaran Pendapatan dan Belanja Negara (APBN). Pada tahun 2017 total belanja PBJ adalah Rp490 Triliun yang terdiri dari belanja barang/jasa Rp296 Triliun dan belanja modal Rp194 Triliun. Sementara total belanja PBJ dari APBD tahun 2017 adalah sebesar RP452 Triliun yang terdiri dari belanja barang/jasa Rp232 Triliun dan belanja modal Rp220 Triliun[1].

Pemerintah terus berusaha untuk meningkatkan kinerja pengadaan barang/jasa dengan melakukan perbaikan baik dari sisi regulasi, pelaksanaan, dan kelembagaan. Namun, hasil pengamatan Indonesian Corruption Watch (ICW) pada tahun 2018 menunjukan bahwa terdapat 61 kasus korupsi bermodus mark up pada proses pengadaan barang dan jasa [2]. Menurut ICW sektor pengadaan barang/jasa sangat berisiko terjadinya korupsi. Sepanjang 2017 telah terjadi 84 kasus dengan kerugian negara mencapai Rp1,2 Triliun [3]. Audit Badan Pemeriksa Keuangan Tahun 2016 mengungkapkan temuan terkait pengadaan barang/jasa yang meliputi kelebihan pembayaran, pemahalan harga, denda keterlambatan yang belum diterima, pengadaan fiktif, spesifikasi barang tidak sesuai kontrak, dan penyedia tidak menyelesaikan pekerjaan dengan kerugian negara mencapai Rp1,15 Triliun [4].

Data tersebut menjadi alasan semakin meningkatnya kekhawatiran terhadap kinerja pengadaan barang/jasa pemerintah. Kinerja pengadaan barang/jasa pemerintah terus menjadi sorotan karena banyaknya kasus korupsi yang berasal dari proses pengadaan barang/jasa. Kekhawatiran ini semakin meningkat dengan keadaan darurat wabah Corona Virus Disease (Covid-19) yang sedang terjadi saat ini. Proses pengadaan barang/jasa menjadi elemen penting dalam mengatasi wabah Covid-19 dengan tuntutan kebutuhan barang dan jasa untuk penanggulangan wabah yang sangat mendesak untuk dapat dipenuhi secepatnya. Pengadaan barang/jasa dalam keadaan darurat menghadapi beberapa masalah seperti kelangkaan barang yang disebabkan rantai suplai barang yang terputus dan kenaikan harga yang tidak wajar [5].

Secara peraturan, proses pengadaan barang/jasa untuk mengatasi situasi wabah ini mengacu pada Peraturan LKPP Nomor 13 Tahun 2018 tentang pengadaan barang/jasa dalam keadaan darurat. Fokus dari peraturan ini adalah penyederhanaan proses pengadaan barang/jasa dalam rangka mempercepat pemenuhan kebutuhan barang/jasa dalam mengatasi situasi wabah.

Penerapan peraturan pengadaan barang/jasa dalam keadaan darurat ini sendiri menimbulkan kekhawatiran. Hal ini berasal dari adanya kewenangan Pejabat Pembuat Komitmen (PPK) yang dapat memilih untuk menunjuk secara langsung penyedia pada proses pengadaan barang/jasa. Kewenangan ini dikhawatirkan dapat meningkatkan potensi terjadinya korupsi yang dapat menurunkan kualitas barang dan jasa yang didapatkan. Selain itu, Peraturan Pengganti Undang-Undang (Perppu) Nomor 1 Tahun 2020 menyebutkan bahwa pejabat perbendaharaan dan pejabat pengadaan barang dan jasa mendapatkan wewenang untuk mengambil tindakan yang dapat menimbulkan beban terhadap APBN walaupun anggarannya masih kurang atau belum tersedia. Kewenangan ini dapat digunakan untuk belanja yang berkaitan dengan penanganan pandemi Covid-19. Kelonggaran peraturan ini dikhawatirkan dapat menurunkan kinerja pengadaan. Kasus korupsi pengadaan barang/jasa dalam keadaan darurat pernah terjadi pada pengadaan alat kesehatan guna mengantisipasi kejadian luar biasa tahun 2005 di Kementerian Kesehatan. Dalam kasus tersebut Siti Fadilah Supari sebagai Menteri Kesehatan menerbitkan surat rekomendasi penunjukan langsung untuk PT Indofarma sebagai penyedia. Kasus ini menyebabkan kerugian negara sebesar Rp6,1 Miliar. Selain itu, pelaksanaan pengadaan alat kesehatan tersebut tidak dilaksanakan tepat waktu sehingga harus dilakukan adendum kontrak [6].

Dalam keadaan darurat seperti ini, menarik untuk meneliti tentang faktor-faktor yang memengaruhi kinerja pengadaan. Penelitian mengenai hal ini telah beberapa kali dilakukan, tetapi semuanya bukan dalam keadaan darurat. Penelitian tentang faktor-faktor yang memengaruhi kinerja pengadaan telah dilakukan pada Otoritas Pengelola Dana Pensiun di Kenya. Penelitian ini menunjukkan bahwa teknologi informasi, manajemen atas, kebijakan pengadaan, dan pelatihan pegawai secara positif memengaruhi kinerja pengadaan [7]. Penelitian pada Perusahaan Minyak Nasional Kenya menunjukkan bahwa peraturan pemerintah dan metode tender berpengaruh positif dan signifikan, sedangkan e-procurement tidak berpengaruh signifikan terhadap kinerja pengadaan [8]. Penelitian di Indonesia menunjukkan bahwa implementasi e-procurement dan kompetensi 
pegawai berpengaruh terhadap kinerja pengadaan barang/jasa di Kementerian Keuangan [9]. Selain itu, penerapan $e-$ procurement dan good governance juga berpengaruh terhadap kinerja pengadaan barang/jasa [10].

Sebagaimana telah disampaikan sebelumnya bahwa kinerja pengadaan barang/jasa sangat dipengaruhi oleh beberapa faktor sebagaimana dikemukakan dalam berbagai penelitian. Faktor faktor tersebut yaitu penerapan kebijakan pengadaan, e-procurement, kompetensi pegawai, dan komitmen manajemen. Penelitian ini akan menggunakan kerangka penelitian sebagaimana ditunjukkan dalam gambar 1.

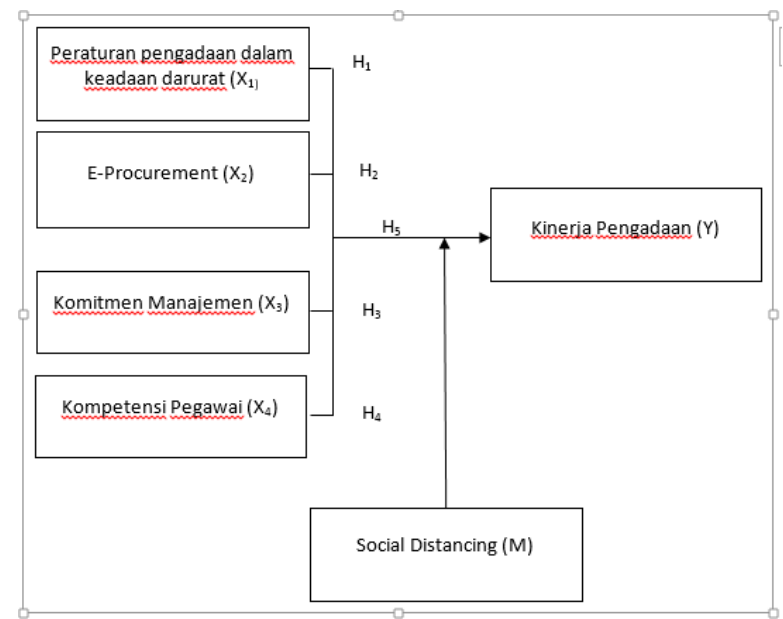

Gambar 1. Kerangka penelitian

Berdasarkan hal tersebut penelitian ini akan menguji pengaruh peraturan pengadaan barang/jasa dalam keadaan darurat, penerapan $e$ procurement, kompetensi pegawai, dan komitmen manajemen terhadap kinerja pengadaan barang/jasa dalam keadaan darurat di Pemerintah Provinsi DKI Jakarta dengan menggunakan social distancing sebagai variabel moderator. Penelitian ini bertujuan untuk menunjukkan faktor-faktor apa saja yang berpengaruh terhadap kinerja pengadaan sehingga manajemen dapat mengambil langkah yang tepat untuk meningkatkan kinerja pengadaan barang/jasa dalam keadaan darurat. Selain itu, penggunaan variabel moderator akan menunjukkan pengaruh social distancing terhadap hubungan faktor-faktor tersebut dengan kinerja pengadaan barang/jasa dalam keadaan darurat.

Penelitian ini menggunakan hipotesis sebagai berikut:

$\mathrm{H}_{1}$ : Penerapan kebijakan pengadaan barang dan jasa dalam keadaan darurat berpengaruh positif dan signifikan terhadap kinerja pengadaan dalam keadaan darurat

$\mathrm{H}_{2}$ : Penerapan e-procurement berpengaruh positif dan signifikan terhadap kinerja pengadaan dalam keadaan darurat

$\mathrm{H}_{3} \quad$ : Kompetensi pegawai berpengaruh positif dan signifikan terhadap kinerja pengadaan dalam keadaan darurat

$\mathrm{H}_{4}$ : Komitmen manajemen berpengaruh positif dan signifikan terhadap kinerja pengadaan dalam keadaan darurat

$\mathrm{H}_{5}$ : Penerapan kebijakan pengadaan barang dan jasa dalam keadaan darurat, e-procurement, kompetensi pegawai, dan komitmen manajemen secara bersama-sama berpengaruh positif dan signifikan terhadap kinerja pengadaan dalam keadaan darurat

$\mathrm{H}_{6}$ : Social distancing memperlemah pengaruh penerapan kebijakan pengadaan barang dan jasa dalam keadaan darurat terhadap kinerja pengadaan dalam keadaan darurat

$\mathrm{H}_{7}$ : Social distancing memperlemah pengaruh penerapan e-procurement berpengaruh positif dan signifikan terhadap kinerja pengadaan dalam keadaan darurat

$\mathrm{H}_{8}$ : Social distancing memperlemah pengaruh kompetensi pegawai terhadap kinerja pengadaan dalam keadaan darurat

$\mathrm{H}_{9}$ : Social distancing memperlemah pengaruh komitmen manajemen terhadap kinerja pengadaan dalam keadaan darurat

\section{METODE PENELITIAN}

Penelitian ini menggunakan data primer. Data primer yang digunakan adalah data hasil kuesioner terhadap responden yaitu pejabat struktural maupun fungsional yang berada di lingkungan Badan Pelayanan Pengadaan Barang/Jasa (BPPBJ) yang memiliki peran dalam proses pengadaan di lingkungan Pemerintah Provinsi DKI Jakarta. Data tersebut akan terdiri dari identitas responden, kompetensi SDM, penerapan e-procurement, kebijakan pengadaan barang/jasa dalam keadaan darurat, komitmen manajemen, dan kinerja pengadaan barang/jasa.

Pengumpulan data melalui kuesioner berasal dari 89 responden dari total 132 pegawai di lingkungan BPPBJ. Jumlah sampel dalam penelitian ini 
ditentukan berdasarkan pada metode penentuan sampel Isaac dan Michael pada tingkat kesalahan $10 \%$ [11]. Penyebaran kuesioner dilakukan melalui hard copy dan daring melalui google form sejak tanggal 29 Juni s.d 24 Juli 2020.

Pertanyaan - pertanyaan dalam kuesioner menggunakan skala likert merujuk pada variabel bebas, yaitu peraturan pengadaan barang/jasa dalam keadaan darurat, penerapan $e$ procurement, kompetensi pegawai, dan komitmen manajemen, variabel terikat kinerja pengadaan barang/jasa dalam keadaan darurat, dan variabel moderator social distancing dengan menggunakan definisi dan indikator sebagai berikut:

\subsection{Kinerja Pengadaan Barang/Jasa dalam Keadaan Darurat}

Kinerja dapat diartikan sebagai sebuah hasil kerja dari seseorang yang dimaksudkan untuk mencapai tujuan yang diinginkan. Ukuran kinerja bergantung pada cakupan pekerjaan yang dilakukan. Indikator pengukuran kinerja yaitu kualitas kerja, kuantitas kerja, tanggung jawab, ketepatan waktu, dan kerja sama dengan orang lain [12]. Indikator pengukuran kinerja dalam penelitian ini akan mengadopsi penelitian sebelumnya [9] sebagaimana disebutkan dalam tabel 1.

Tabel 1. Indikator Pengukuran Kinerja Pengadaan Barang/Jasa dalam Keadaan Darurat

\begin{tabular}{cl}
\hline \multicolumn{1}{c}{ Variabel } & Indikator Pengukuran \\
\hline \multirow{3}{*}{ Kinerja pengadaan } & 1. Kualitas Pekerjaan \\
& 2. Kuantitas Pekerjaan \\
& 3. Ketepatan waktu \\
& pekerjaan \\
\hline
\end{tabular}

\subsection{Peraturan Pengadaan Barang/Jasa dalam Keadaan Darurat}

Penetapan status tanggap darurat bencana yang dikeluarkan oleh Kepala BNPB menjadi dasar untuk diterapkannya peraturan pengadaan barang/jasa dalam keadaan darurat yang diatur dalam Peraturan LKPP Nomor 13 Tahun 2018. Peraturan ini melakukan penyederhanaan proses pengadaan barang/jasa dengan memberikan kewenangan kepada PPK dalam menunjuk secara langsung penyedia untuk mempermudah pencarian penyedia dan mempercepat proses pengadaan. Hal ini diperkuat dengan Instruksi Presiden Nomor 4 Tahun 2020 yang memerintahkan adanya percepatan proses pengadaan barang/jasa. Indikator pengukuran variabel ini disebutkan dalam tabel 2.
Tabel 2. Indikator Pengukuran Peraturan PBJ dalam Keadaan Darurat

\begin{tabular}{|c|c|}
\hline Variabel & Indikator Pengukuran \\
\hline $\begin{array}{l}\text { Peraturan PBJ dalam } \\
\text { keadaan darurat }\end{array}$ & $\begin{array}{l}\text { 1. Perubahan metode } \\
\text { tender } \\
\text { 2. Ketersediaan akses } \\
\text { terhadap supplier } \\
\text { 3. Ketersediaan } \\
\text { dokumentasi } \\
\text { pengadaan }\end{array}$ \\
\hline
\end{tabular}

\subsection{Penerapan E-procurement}

E-procurement digunakan dalam proses pengadaan barang/jasa untuk memperbaiki kekurangan-kekurangan yang dimiliki oleh proses pengadaan secara manual. Penerapan eprocurement diharapkan dapat memperbaiki kinerja pengadaan dan menutupi kelemahankelemahan yang ada. Kesuksesan penerapan $e$ procurement ditentukan oleh beberapa faktor, yaitu e-leadership, transformasi pola pikir dan pola tindak, dan ketersediaan infrastruktur [13]. Selanjutnya kesuksesan penerapan $e$ procurement akan memperbaiki kinerja pengadaan barang/jasa pemerintah. Tabel 3 menjelaskan indikator pengukuran yang digunakan dalam penelitian ini.

Tabel 3. Indikator Pengukuran Penerapan Eprocurement

\begin{tabular}{cc}
\hline Variabel & Indikator Pengukuran \\
\hline & 1. E-leadership \\
$\begin{array}{c}\text { Penerapan } e- \\
\text { 2. Transformasi pola pikir } \\
\text { procurement }\end{array}$ & $\begin{array}{c}\text { dan pola tindak } \\
\text { 3. Ketersediaan } \\
\text { Infrastruktur }\end{array}$ \\
\hline
\end{tabular}

\subsection{Kompetensi Pegawai}

Keberhasilan sebuah organisasi dalam menjalankan sistem sangat dipengaruhi oleh sumber daya manusia yang dimiliki. Dalam mengukur kompetensi pegawai, Zwell memberikan lima unsur kompetensi, yaitu task achievement, relationship, personal attribute, managerial, dan leadership [14]. Indikator pengukuran dalam penelitian ini akan mengikuti penelitian sebelumnya [9] dengan menentukan indicator sebagaimana disebutkan dalam tabel 4 berikut ini : 
Tabel 4. Indikator Pengukuran Kompetensi Pegawai

\begin{tabular}{cl}
\hline Variabel & \multicolumn{1}{c}{ Indikator Pengukuran } \\
\hline \multirow{3}{*}{ Kompetensi pegawai } & 1. Pengetahuan \\
& 2. Keterampilan \\
& 3. Motivasi \\
& 4. Karakteristik Pribadi \\
\hline
\end{tabular}

\subsection{Komitmen Manajemen}

Komitmen manajemen terwujud ketika seorang manajer sebuah perusahaan atau divisi menerima tanggung jawab untuk keberhasilan implementasi rencana bisnis. Manajer harus terlibat dan menambahkan keahlian dan bakat khusus yang membuatnya menjadi presiden. Komitmen penting bagi organisasi karena menunjukkan kepercayaan pada manajer dan keinginan untuk terus memberikan nilai dalam pelayanan yang diberikan [15]. Pengukuran komitmen manajemen akan menggunakan indikator berdasarkan penelitian [16] sebagaimana dalam tabel dalam tabel 5.

Tabel 5. Indikator Pengukuran Komitmen Manajemen

\begin{tabular}{|c|c|}
\hline Variabel & Indikator Pengukuran \\
\hline $\begin{array}{c}\text { Komitmen } \\
\text { manajemen }\end{array}$ & $\begin{array}{l}\text { 1. Persepsi pegawai mengenai } \\
\text { dukungan pelatihan dari pimpinan } \\
\text { 2. Persepsi pegawai mengenai } \\
\text { pemberdayaan pegawai } \\
\text { 3. Persepsi pegawai mengenai } \\
\text { reward and punishment } \\
\text { 4. Persepsi pegawai mengenai } \\
\text { alokasi sumber daya } \\
\text { 5. Persepsi pegawai mengenai } \\
\text { kepemimpinan } \\
\text { penyelesaian masalah dalam }\end{array}$ \\
\hline
\end{tabular}

\subsection{Social Distancing}

Social distancing merupakan salah satu langkah pencegahan dan pengendalian infeksi Covid-19 yang diwujudkan dengan anjuran untuk berdiam diri di rumah dan pembatasan kegiatan di tempat umum untuk mengurangi kontak dengan orang lain. Interaksi yang sering dilakukan baik antara sesame pegawai, antara pegawai dan pelanggan, antara pegawai dan peralatan meningkatkan produktivitas [17]. Dalam penelitian [17] mengukur pelaksanaan social distancing dengan menggunakan indeks kerjasama tim, pelanggan dan kehadiran. Tabel 6 menjelaskan indikator pengukuran yang digunakan tersebut dalam skema penelitian ini dengan rincian sebagai berikut :.
Tabel 6. Indikator Pengukuran Social Distancing

\begin{tabular}{cl}
\hline Variabel & \multicolumn{1}{c}{$\begin{array}{c}\text { Indikator } \\
\text { Pengukuran }\end{array}$} \\
\hline & 1. Pembatasan \\
kerjasama tim \\
Social & 2. Pembatasan \\
interaksingelanggan & $\begin{array}{l}\text { 3. Pembatasan } \\
\text { kehadiran di kantor }\end{array}$ \\
\hline
\end{tabular}

Penelitian ini bertujuan untuk menganalisis faktor yang memengaruhi kinerja pengadaan barang/jasa dalam keadaan darurat. Faktor yang menjadi variabel bebas dalam penelitian ini adalah kebijakan pengadaan barang/jasa dalam keadaan darurat, penerapan e-procurement, kompetensi pegawai, dan komitmen manajemen. Selain itu, untuk menggambarkan kondisi darurat yang terjadi, ditambahkan variabel moderator yaitu social distancing.

Terdapat dua model penelitian yang akan digunakan dalam penelitian ini. Yang pertama digunakan untuk menganalisa hubungan variabel bebas terhadap variabel terikat. Yang kedua digunakan untuk menganalisa pengaruh variabel moderator terhadap pengaruh variabel bebas terhadap variabel terikat.

$$
\begin{aligned}
& \mathrm{KIN}=\alpha+\beta_{1} \mathrm{PBJ}+\beta_{2} \mathrm{EPROC}+\beta_{3} \mathrm{KP}+\beta_{4} \mathrm{KM} \\
& \mathrm{KIN}=\alpha+\beta_{1} \mathrm{PBJ}+\beta_{2} \mathrm{EPROC}+\beta_{3} \mathrm{KP}+\beta_{4} \mathrm{KM} \\
& +\beta_{5} \mathrm{PBJ} \mathrm{SD}+\beta_{6} \mathrm{EPROC} \mathrm{SD}+\beta_{7} \mathrm{KP} \mathrm{SD}+ \\
& \beta_{8} \mathrm{KM} \text { SD }
\end{aligned}
$$

\section{Keterangan:}

$\mathrm{KIN}=$ Kinerja Pengadaan

$\alpha=$ Konstanta

$\beta=$ Slope

$\mathrm{PBJ}=$ Kebijakan Pengadaan Barang/Jasa dalam

Keadaan Darurat

$\mathrm{EPROC}=$ E-Procurement

$\mathrm{KP}=$ Kompetensi Pegawai

$\mathrm{KM}=$ Komitmen Manajemen

Sebelum digunakan dalam analisis data, data yang diperoleh melalui kuesioner telah melalui uji validitas, uji reliabilitas, dan uji asumsi klasik yang terdiri dari uji multikolonieritas, uji normalitas, dan uji heteroskedastisitas. Selanjutnya uji hipotesis menggunakan uji statistik $\mathrm{f}$, uji statistik $\mathrm{t}$, dan Moderated Regression Analysis (MRA). 


\section{HASIL DAN PEMBAHASAN}

\subsection{Hasil Uji Validitas}

Hasil uji validitas telah dilakukan terhadap semua pertanyaan pada masing-masing variabel penelitian. Metode yang digunakan dalam pengujian ini adalah metode Bivariate Pearson. Pengujian ini dilakukan dengan cara membandingkan jumlah $r$ hasil perhitungan ( $r$ hitung) dengan $r$ tabel dari setiap pertanyaan pada kuesioner penelitian. Uji validitas data dilakukan terhadap 89 responden dan diperoleh nilai r-tabel sebesar 0,213 . Nilai r-tabel diperoleh dengan menentukan koefisien korelasi sebanyak 87 (jumlah sampel dikurangi 2) dan tingkat signifikansi (a) sebesar 5\%. Hasil uji validitas menunjukkan bahwa seluruh item pertanyaan yang digunakan dalam kuesioner menghasilkan nilai $r$ yang lebih besar dari $r$ tabel.

\subsection{Hasil Uji Reliabilitas}

Uji reliabilitas dalam penelitian ini menggunakan metode Cronbach's Alpha aplikasi SPSS. Hasil pengujian menunjukkan bahwa seluruh variabel yang digunakan dalam penelitian menghasilkan nilai Cronbach's Alpha lebih dari 0,600. Hasil ini menunjukkan bahwa seluruh variabel memiliki nilai reliabilitas yang baik dan dapat diterima. Ikhtisar hasil pengujian untuk setiap variabel disajikan dalam tabel 7.

Tabel. 7 Hasil uji reliabilitas variabel penelitian

\begin{tabular}{lcc}
\hline \multicolumn{1}{c}{ Variabel } & $\begin{array}{c}\text { Jumlah } \\
\text { Pertanyaan }\end{array}$ & $\begin{array}{c}\text { Cronbach's } \\
\text { Alpha }\end{array}$ \\
\hline $\begin{array}{l}\text { Kebijakan } \\
\text { Pengadaan }\end{array}$ & 6 & 0,837 \\
$\begin{array}{l}\text { Kompetensi } \\
\text { Pegawai }\end{array}$ & 4 & 0,890 \\
$\begin{array}{l}\text { E-Procurement } \\
\text { Komitmen }\end{array}$ & 6 & 0,846 \\
$\begin{array}{l}\text { Manajemen } \\
\text { Social }\end{array}$ & 7 & 0,821 \\
$\begin{array}{l}\text { Distancing } \\
\text { Kinerja }\end{array}$ & 4 & 0,635 \\
Pengadaan & 6 & 0,815 \\
\hline
\end{tabular}

\subsection{Hasil Uji Asumsi Klasik}

Uji asumsi klasik pertama yang dilakukan adalah uji multikolonieritas. Uji multikolonieritas bertujuan untuk mengetahui korelasi antarvariabel yang terdapat dalam penelitian. Penelitian yang menggunakan analisis regresi berganda tidak boleh memiliki masalah kolonieritas [18]. Indikasi mutikolonieritas dapat diukur dengan menggunakan nilai statistik kolinearitas tolerance dan VIF. Dari gambar 2 tabel koefisien menunjukkan bahwa seluruh variabel memiliki nilai tolerance lebih dari 0,01 dan nilai VIF kurang dari 10. Hal ini menunjukkan bahwa dalam model penelitian ini tidak ada masalah multikolonieritas.

\begin{tabular}{|c|c|c|c|c|c|c|}
\hline \multicolumn{7}{|c|}{ Coefficient Correlations $^{\mathrm{a}}$} \\
\hline Model & & & $\mathrm{KM}$ & $\mathrm{KP}$ & PBJ & EP \\
\hline \multirow[t]{8}{*}{1} & \multirow{4}{*}{ Correlations } & $\mathrm{KM}$ & 1.000 & .087 & -.079 & -.370 \\
\hline & & $\mathrm{KP}$ & .087 & 1.000 & -.091 & -.519 \\
\hline & & PBJ & -.079 & -.091 & 1.000 & -.303 \\
\hline & & EP & -.370 & -.519 & -.303 & 1.000 \\
\hline & \multirow[t]{4}{*}{ Covariances } & $\mathrm{KM}$ & .007 & .001 & -.001 & -.003 \\
\hline & & $\mathrm{KP}$ & .001 & .015 & -.001 & -.007 \\
\hline & & PBJ & -.001 & -.001 & .008 & -.003 \\
\hline & & EP & -.003 & -.007 & -.003 & .012 \\
\hline
\end{tabular}

Gambar. 2 Hasil uji koefisien korelasi

Setelah melakukan uji multikolonieritas, uji asumsi klasik yang diterapkan dalam menguji model penelitian ini adalah uji normalitas. Uji normalitas bertujuan untuk mengetahui distribusi data yang telah didapatkan melalui kuesioner. Data yang baik adalah data yang memiliki distribusi normal. Hal ini berarti bahwa data tersebut memiliki sebaran data normal dalam arti kata data yang digunakan tersebut dapat mewakili sebuah populasi [19]. Hasil uji normalitas dengan menggunakan grafik histogram residual sebagaiman ditunjukkan dalam gambar 3 menunjukkan bentuk yang membentuk lengkung normal dengan tidak memenceng ke kiri atau ke kanan. Hasil ini sesuai dengan kriteria uji normalitas yang telah ditentukan sehingga dapat disimpulkan bahwa sebaran data yang dikumpulkan terdistribusi secara normal dan dapat digunakan lebih lanjut dalam melakukan analisis data pada penelitian ini

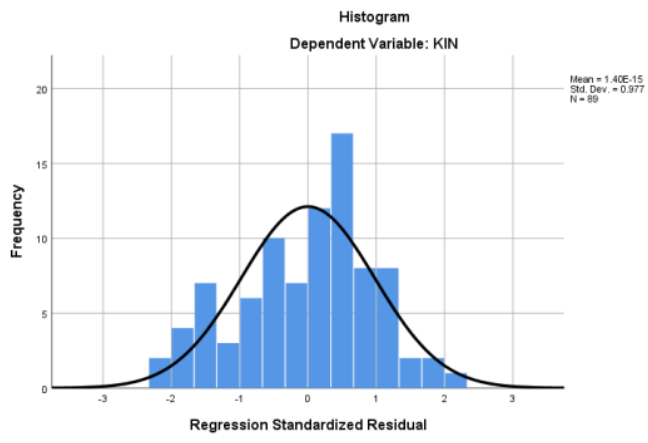

Gambar. 3 Grafik histogram hasil uji normalitas

Hasil grafik scatterplot pada model penelitian menunjukkan bahwa titik-titik tersebar diatas dan dibawah angka 0 sehingga tidak terjadi pengumpulan hanya di salah satu sisi. Pola 
penyebaran juga tidak mengindikasikan adanya pola tertentu. Hasil ini menunjukkan bahwa kriteria dalam uji heteroskedastisitas grafik scatterplot telah terpenuhi sehingga dapat disimpulkan bahwa model regresi yang dipakai layak digunakan dalam memprediksi kinerja pengadaan

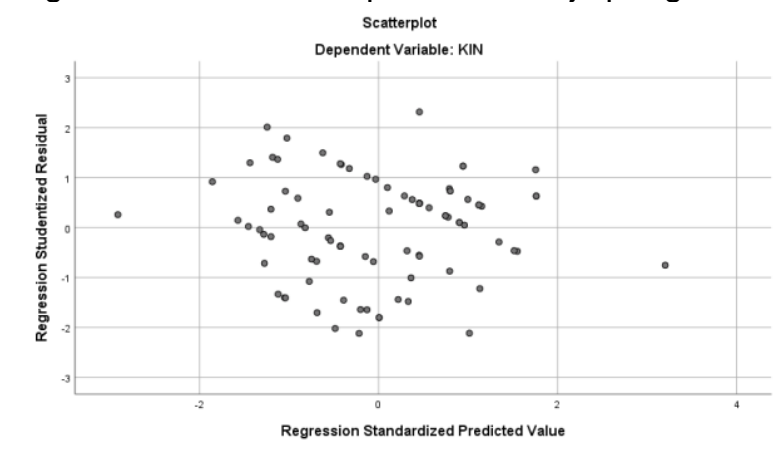

Gambar. 4 Grafik scatterplot hasil uji heteroskedastisitas

\subsection{Hasil Uji Statistik f}

Uji hipotesis pertama yang dilakukan dalam penelitian ini adalah regresi linear berganda dengan uji statistik F. Pengujian ini dilakukan untuk mengetahui pengaruh variabel bebas secara bersama-sama terhadap variabel terikat dan mengetahui signifikansi dari model regresi yang digunakan dalam penelitian [20]. Nilai Fhitung yang diperoleh dengan menggunakan SPSS adalah sebesar 16,277 dan signifikansi sebesar 0,000 sebagaimana ditunjukkan dalam gambar 5.

\begin{tabular}{|c|c|c|c|c|c|c|}
\hline \multicolumn{7}{|c|}{ ANOVA $^{a}$} \\
\hline \multicolumn{2}{|c|}{ Model } & $\begin{array}{l}\text { Sum of } \\
\text { Squares }\end{array}$ & df & Mean Square & $\mathrm{F}$ & Sig. \\
\hline \multirow[t]{3}{*}{1} & Regression & 528.606 & 4 & 132.151 & 16.277 & $.000^{\mathrm{b}}$ \\
\hline & Residual & 682.004 & 84 & 8.119 & & \\
\hline & Total & 1210.610 & 88 & & & \\
\hline \multicolumn{7}{|c|}{ a. Dependent Variable: KIN } \\
\hline \multicolumn{7}{|c|}{ b. Predictors: (Constant), KM, KP, PBJ, EP } \\
\hline
\end{tabular}

Gambar 5. Hasil uji statistik f menggunakan SPSS

Hasil tersebut menunjukkan bahwa variabel bebas secara bersama-sama memberikan pengaruh signifikan terhadap kebijakan pengadaan barang/jasa dalam keadaan darurat. dengan demikian hipotesis yang menyatakan bahwa kebijakan pengadaan dalam keadaan darurat, kompetensi pegawai, penerapan $e$ procurement, dan komitmen manajemen secara bersama-sama berpengaruh signifikan terhadap kinerja pengadaan barang/jasa dalam keadaan darurat dapat diterima dan diberlakukan pada populasi tempat pengambilan sampel.

\subsection{Hasil Uji Statistik t}

Uji hipotesis kedua yang dilakukan adalah uji statistik $t$ atau uji parsial. Uji ini dilakukan untuk mengetahui pengaruh variabel bebas terhadap variabel terikat secara parsial [20]. Hasil uji regresi parsial yang menunjukkan t-hitung dan signifikansi variabel bebas dalam model penelitian ini ditampilkan dalam gambar 6 .

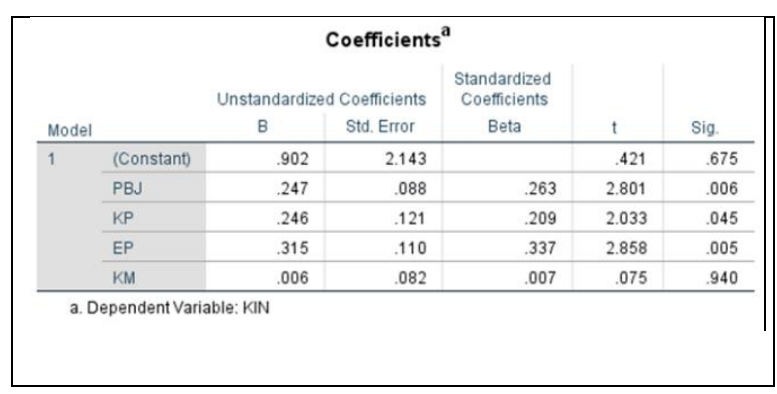

Gambar 6. Hasil uji statistik t menggunakan SPSS

Variabel kebijakan pengadaan barang/jasa dalam keadaan darurat mendapatkan nilai koefisien regresi bertanda positif sebesar 0,247 dengan nilai t hitung sebesar 2,801 dan nilai signifikansi sebesar 0,006. Hal ini berarti bahwa hipotesis yang menyatakan bahwa kebijakan pengadaan barang/jasa dalam keadaan darurat berpengaruh positif dan signifikan terhadap kinerja pengadaan dalam keadaan darurat dapat diterima dan diberlakukan pada populasi tempat pengambilan sampel.

Variabel kompetensi pegawai mendapatkan nilai koefisien regresi bertanda positif sebesar 0,246 dengan nilai $t$ hitung sebesar 2,033 dan nilai signifikansi sebesar 0,045. Hal ini berarti bahwa hipotesis yang menyatakan bahwa kompetensi pegawai berpengaruh positif dan signifikan terhadap kinerja pengadaan dalam keadaan darurat dapat diterima dan diberlakukan pada populasi tempat pengambilan sampel.

Variabel penerapan e-procurement mendapatkan nilai koefisien regresi bertanda positif sebesar 0,315 dengan nilai t hitung sebesar 2,858 dan nilai signifikansi sebesar 0,005. Hal ini berarti bahwa hipotesis yang menyatakan bahwa penerapan $e$ procurement berpengaruh positif dan signifikan terhadap kinerja pengadaan dalam keadaan darurat dapat diterima dan diberlakukan pada populasi tempat pengambilan sampel. 
Variabel komitmen manajemen mendapatkan nilai koefisien regresi bertanda positif sebesar 0,006 dengan nilai $t$ hitung sebesar 0,075 dan nilai signifikansi sebesar 0,940 . Hal ini berarti bahwa hipotesis yang menyatakan bahwa komitmen manajemen berpengaruh positif dan signifikan terhadap kinerja pengadaan dalam keadaan darurat tidak dapat diterima dan tidak diberlakukan pada populasi tempat pengambilan sampel.

\subsection{Hasil MRA}

Uji MRA dalam penelitian ini digunakan untuk menguji pengaruh variabel moderator social distancing terhadap kekuatan korelasi antara variabel bebas dengan variabel terikat. MRA merupakan aplikasi khusus regresi berganda linear dimana dalam persamaan regresinya mengandung unsur interaksi (perkalian dua atau lebih variabel independen) [21].

Variabel interaksi antara social distancing dengan kebijakan pengadaan barang/jasa dalam keadaan darurat mendapatkan nilai koefisien regresi bertanda positif sebesar 0,013 dengan nilai $t$ hitung sebesar 0,283 dan nilai signifikansi sebesar 0,778 . Hal ini berarti bahwa hipotesis yang menyatakan bahwa social distancing memperlemah pengaruh kebijakan pengadaan terhadap kinerja pengadaan barang/jasa dalam keadaan darurat tidak dapat diterima dan tidak dapat diberlakukan pada populasi tempat pengambilan sampel.

Variabel interaksi antara social distancing dengan kompetensi pegawai mendapatkan nilai koefisien regresi bertanda negatif sebesar $-0,084$ dengan nilai t hitung sebesar $-1,377$ dan nilai signifikansi sebesar 0,172 . Hal ini berarti bahwa hipotesis yang menyatakan bahwa social distancing memperlemah pengaruh kompetensi pegawai terhadap kinerja pengadaan barang/jasa dalam keadaan darurat tidak dapat diterima dan tidak dapat diberlakukan pada populasi tempat pengambilan sampel.

Variabel interaksi antara social distancing dengan penerapan e-procurement mendapatkan nilai koefisien regresi bertanda positif sebesar 0,053 dengan nilai $t$ hitung sebesar 1,028 dan nilai signifikansi sebesar 0,307. Hal ini berarti bahwa hipotesis yang menyatakan bahwa social distancing memperlemah pengaruh penerapan $e$ procurement terhadap kinerja pengadaan barang/jasa dalam keadaan darurat tidak dapat diterima dan tidak dapat diberlakukan pada populasi tempat pengambilan sampel.
Variabel interaksi antara social distancing dengan komitmen manajemen mendapatkan nilai koefisien regresi bertanda negatif sebesar $-0,031$ dengan nilai $t$ hitung sebesar $-0,778$ dan nilai signifikansi sebesar 0,251 . Hal ini berarti bahwa hipotesis yang menyatakan bahwa social distancing memperlemah pengaruh penerapan $e$ procurement terhadap kinerja pengadaan barang/jasa dalam keadaan darurat tidak dapat diterima dan tidak dapat diberlakukan pada populasi tempat pengambilan sampel.

Secara keseluruhan uji hipotesis yang dilakukan menunjukkan bahwa $\mathrm{H}_{1}, \mathrm{H}_{2}, \mathrm{H}_{3}$, dan $\mathrm{H}_{5}$ diterima sedangkan $\mathrm{H}_{4}, \mathrm{H}_{6}, \mathrm{H}_{7}, \mathrm{H}_{8}$, dan $\mathrm{H}_{9}$ ditolak.

\subsection{Interpretasi Hasil Penelitian}

Pengujian statistik $\mathrm{t}$ dan $\mathrm{F}$ yang telah dilakukan menghasilkan nilai untuk setiap koefisien untuk persamaan regresi pada model penelitian 1 . Nilai koefisien tersebut dapat diterapkan terhadap persamaan regresi sehingga dapat dibuat persamaan menjadi sebagai berikut:

$$
\begin{aligned}
\mathrm{KIN}= & 0,902+0,247 \mathrm{PBJ} \\
& +0,246 \mathrm{KP}+0,315 \mathrm{EP}+ \\
& 0,006 \mathrm{KM}
\end{aligned}
$$

Uji statistik $t$ juga dilakukan terhadap model penelitian 2 dengan menggunakan metode MRA. Pengujian statistik $t$ yang dilakukan telah menghasilkan nilai untuk setiap koefisien yang digunakan dalam persamaan regresi model penelitian 2. Nilai koefisien tersebut dapat

\begin{tabular}{|c|c|}
\hline $\begin{array}{c}\text { Kinerja } \\
\text { pengadaan } \\
\text { barang jasa } \\
\text { dalam keadaan } \\
\text { darurat }\end{array}$ & $\begin{aligned}= & -6,515+0,8 \mathrm{PBJ} \\
& +1,351 \mathrm{KP}-0,367 \mathrm{EP} \\
& +0,412 \mathrm{KM}+0,534 \mathrm{SD} \\
& +0,013 \mathrm{SDPBJ} \\
& -0,084 \mathrm{SDKP}+0,05 \\
& \text { SDEP }-0031 \mathrm{SDKM}\end{aligned}$ \\
\hline
\end{tabular}
diterapkan pada persamaan regresi sehingga didapatkan persamaan sebagai berikut:

Berdasarkan hasil analisis regresi menggunakan dua model penelitian, maka dapat disampaikan hal-hal sebagai berikut:

1. Model penelitian 1 menjelaskan pengaruh variabel bebas yaitu, kebijakan pengadaan, kompetensi pegawai, e-procurement, dan komitmen manajemen atas terhadap variabel terikat kinerja pengadaan dalam keadaan darurat. Hasil analisis menyatakan bahwa tiga variabel terikat berpengaruh positif dan signifikan terhadap variabel terikat.

2. Model penelitian 2 menggunakan metode MRA untuk menjelaskan pengaruh variabel 
moderator terhadap hubungan variabel bebas dengan variabel terikat. Dari analisis yang dilakukan dapat diambil kesimpulan bahwa variabel moderator tidak berpengaruh terhadap hubungan antara variabel bebas dengan variabel terikat.

3. Dari hasil analisis menggunakan dua model penelitian dapat diambil kesimpulan bahwa model penelitian 1 lebih dapat menjelaskan situasi di lapangan terkait kinerja pengadaan barang/jasa. Kinerja pengadaan barang/jasa dipengaruhi oleh kebijakan pengadaan, penerapan e-procurement, kompetensi pegawai, dan komitmen manajemen. Penggunaan variabel moderator dalam model penelitian 2 tidak menghasilkan pengaruh yang signifikan terhadap hubungan variabel bebas terhadap variabel terikat.

\subsection{Pembahasan Hasil Penelitian}

Kinerja pengadaan barang/jasa dalam keadaan darurat telah berjalan dengan baik. Hal ini mengacu pada tiga indikator pengukuran dalam menilai kinerja pengadaan barang/jasa. Indikator tersebut adalah kualitas, kuantitas, dan ketepatan waktu pekerjaan pengadaan barang/jasa. Kinerja pengadaan barang/jasa dalam keadaan darurat telah berhasil menyediakan barang/jasa secara tepat waktu sesuai dengan kualitas dan kuantitas yang dibutuhkan.

Secara teoritis, kinerja pengadaan barang/jasa dipengaruhi oleh beberapa faktor yaitu kebijakan pengadaan barang/jasa, pelatihan pegawai, teknologi informasi, dan dukungan manajemen atas [7]. Penelitian yang dilakukan untuk mengetahui faktor-faktor yang memengaruhi kinerja pengadaan barang/jasa dalam keadaan darurat memberikan bukti bahwa faktor-faktor tersebut memang berpengaruh terhadap kinerja pengadaan barang/jasa dalam keadaan darurat.

Hasil penelitian menunjukkan bahwa terdapat tiga faktor yang dapat memberikan pengaruh positif dan signifikan terhadap kinerja pengadaan barang/jasa dalam keadaan darurat. faktor-faktor tersebut adalah kebijakan pengadaan barang/jasa dalam keadaan darurat, kompetensi pegawai, dan penerapan e-procurement. Hasil penelitian terhadap tiga faktor dalam penelitian ini sesuai dengan hasil penelitian sebelumnya. Sedangkan satu faktor lainnya yaitu komitmen manajemen berpengaruh positif namun tidak signifikan. Hasil penelitian ini menunjukkan bahwa jika organisasi dapat mengelola faktor-faktor tersebut dengan baik, maka kinerja pengadaan barang/jasa akan menjadi semakin efektif. Akan tetapi, jika faktor- faktor tersebut tidak dikelola dengan baik, maka kinerja pengadaan barang/jasa dalam keadaan darurat akan menurun.

Penelitian ini juga menggunakan social distancing sebagai variabel moderator. Variabel ini digunakan untuk menunjukkan pengaruh social distancing terhadap hubungan faktor-faktor tersebut terhadap kinerja pengadaan barang/jasa dalam keadaan darurat. Hasil penelitian menunjukkan bahwa kebijakan social distancing yang diterapkan pemerintah tidak memperlemah pengaruh faktor-faktor tersebut terhadap kinerja pengadaan barang/jasa dalam keadaan darurat. Hal ini dapat terjadi karena pekerjaan yang dilakukan telah banyak menggunakan teknologi informasi. Sehingga dalam hal komunikasi terkait penyelesaian pekerjaan dapat dilakukan meskipun tidak bertatap muka.

Penelitian menunjukkan bahwa untuk menghasilkan kinerja pengadaan barang/jasa , diperlukan kebijakan pengadaan barang/jasa dalam keadaan darurat yang berkualitas. Salah satu kendala yang menghambat terlaksananya proses pengadaan dengan baik adalah kompleksitas proses pengadaan itu sendiri. Kompleksitas yang ada dalam peraturan pengadaan barang/jasa memperpanjang waktu proses pengadaan dan menyebabkan inefisiensi [22].

Selain itu, ketidakwajaran harga yang terjadi selama keadaan darurat dapat menimbulkan keengganan bagi pelaku pengadaan untuk mengeksekusi paket pengadaan. Hal ini mengingat konsekuensi hukum yang akan dihadapi pelaku pengadaan bila terdapat unsur kerugian negara yang terjadi. Salah satu risiko dalam pengadaan barang/jasa adalah masalah tindak pidana korupsi [23].

Hasil penelitian menunjukkan bahwa Peraturan LKPP Nomor 13 Tahun 2020 telah banyak digunakan sebagai landasan untuk pelaksanaan pengadaan barang/jasa dalam keadaan darurat. Hal ini menunjukkan bahwa jaminan hukum yang diberikan oleh peraturan yang ada telah mengusir keengganan para pelaku pengadaan untuk mengeksekusi paket pengadaan

Penelitian menunjukkan bahwa untuk menghasilkan kinerja pengadaan barang/jasa dalam keadaan darurat, diperlukan pegawai yang memiliki kompetensi yang baik. Hal ini sesuai dengan penelitian yang menyebutkan bahwa pengetahuan diperlukan untuk efektivitas implementasi [24] dan pelaksanaan pengadaan 
barang/jasa [25]. Pengetahuan terkait peraturan yang berlaku dapat membantu terlaksananya penerapan best practice dalam pengadaan barang/jasa [22].

Penerapan sistem e-procurement dalam proses pengadaan barang/jasa merupakan salah satu faktor yang dapat meningkatkan kinerja pengadaan barang/jasa. Hasil penelitian menunjukkan bahwa penerapan sistem $e-$ procurement telah berjalan dengan baik. Kondisi ini sesuai dengan teori yang menyatakan bahwa kinerja sebuah organisasi dapat ditingkatkan dengan menggunakan sistem informasi dan teknologi yang memadai [26].

Komitmen manajemen tidak berpengaruh signifikan terhadap kinerja pengadaan barang/jasa dalam keadaan darurat. Hasil penelitian ini tidak sesuai dengan teori Upper Echelons yang menyebutkan bahwa partisipasi langsung dari manajemen atas terhadap aspek penting dalam organisasi akan meningkatkan kinerja organisasi.

Hasil penelitian menunjukkan bahwa komitmen manajemen dalam organisasi telah dilaksanakan dengan baik. Hal ini ditunjukkan dengan komitmen manajemen dalam menyediakan fasilitas pelatihan dan memberikan kesempatan para pegawai untuk menyampaikan ide. Kedua hal tersebut akan meningkatkan kinerja organisasi. merujuk pada teori scientific management, organisasi telah melakukan langkah yang tepat dengan memiliki ukuran kinerja dan aturan reward and punishment yang jelas. Hal ini dilakukan untuk meningkatkan kinerja organisasi. Sementara itu, beban pekerjaan dan alokasi sumber daya telah dilakukan secara proporsional. Hal ini dilakukan untuk menghindari ketimpangan pekerjaan yang akan menyebabkan beban pekerjaan menjadi lebih berat dan menurunkan kinerja organisasi.

Inkonsistensi hasil penelitian dengan teori ini dapat disebabkan oleh faktor komitmen manajemen langsung bukan merupakan faktor yang terkait secara langsung dalam proses pengadaan barang/jasa. Hal ini karena proses pengadaan barang/jasa tidak memerlukan keterlibatan secara langsung dari manajemen tingkat atas. Mekanisme pengadaan yang dilakukan telah menggunakan sebuah sistem yang mapan dengan dukungan sistem elektronik dan regulasi yang lengkap dan jelas sehingga pegawai tidak memerlukan dukungan dari manajemen atas.
Hasil penelitian ini dapat menjadi dasar bagi manajemen untuk mengambil langkah yang tepat dalam meningkatkan kinerja pengadaan. Penerapan e-procurement merupakan faktor yang memiliki pengaruh yang paling signifikan. Oleh karena itu, untuk meningkatkan kinerja pengadaan, manajemen dapat lebih fokus dalam meningkatkan kualitas dan peran e-procurement dalam pengadaan barang/jasa. Manajemen dapat mengarahkan pelaku pengadaan untuk dapat selalu mengutamakan penggunaan sistem $e$ procurement dalam melaksanakan proses pengadaan. Hal ini dapat dilakukan dengan terus meningkatkan jumlah produk yang terdaftar dalam katalog elektronik sehingga semakin banyak paket pengadaan yang dapat dilakukan melalui katalog elektronik. Selain itu, agar para penyedia tertarik untuk mendaftarkan prduknya didalam katalog elektronik, dapat dilakukan penyederhanaan proses pendaftaran bagi penyedia.

\section{KESIMPULAN}

Penelitian mengenai faktor - faktor yang memengaruhi kinerja pengadaan barang/jasa dalam keadaan darurat bertujuan untuk mengetahui pengaruh faktor kebijakan pengadaan barang/jasa dalam keadaan darurat, kompetensi pegawai, penerapan e-procurement, dan komitmen manajemen di lingkungan Pemerintah Provinsi DKI Jakarta. Hasil penelitian menunjukkan bahwa pengadaan barang/jasa dalam keadaan darurat yang dilakukan telah menghasilkan kinerja yang baik. Hal ini ditopang oleh peraturan pengadaan barang/jasa dalam keadaan darurat, kompetensi pegawai, dan penerapan e-procurement.

Selain itu, hasil penelitian juga menunjukkan bahwa penerapan social distancing dianggap tidak memoderasi pengaruh empat faktor terhadap kinerja pengadaan barang/jasa. Hal ini dapat terjadi karena penggunaan teknologi informasi memungkinkan komunikasi dalam penyelesaian tugas tetap terjaga sehingga kinerja pengadaan barang dan jasa tidak terganggu. Faktor - faktor yang berpengaruh telah berhasil menopang kinerja pengadaan barang/jasa dalam masa wabah Covid-19.

Penelitian ini masih memiliki ruang untuk pengembangan yang dapat dilaksanakan dalam penelitian - penelitian selanjutnya dengan menggunakan populasi dan sampel yang lebih luas, menambahkan faktor lain yang dapat memengaruhi kinerja pengadaan barang/jasa, dan melengkapi indikator pengukuran variabel yang digunakan. 


\section{DAFTAR PUSTAKA}

[1] W. Wardiana, "Sosialisasi Pencegahan Korupsi pada Pengadaan Barang dan Jasa," 2017. http://www.romadan.kemenkeu.go.id/Mod $\mathrm{ul} /$ GetPdfFile?fileName=Sosialisasi Pencegahan Korupsi PBJ.pdf (accessed Nov. 12, 2020).

[2] W. Alamsyah, L. Abid, and A. Sunaryanto, "Laporan Tren Penindakan Kasus Korupsi Tahun 2018," 2018. [Online]. Available: https://antikorupsi.org/sites/default/files/la poran_tren_penindakan_kasus_korupsi_2 018.pdf.

[3] S. Wildansyah, "ICW: Korupsi Pengadaan Barang 2017 Meningkat, Negara Rugi Rp 1 T," Detik.com, 2018. https://news.detik.com/berita/d3885311/icw-korupsi-pengadaan-barang2017-meningkat-negara-rugi-rp-1-t (accessed Sep. 16, 2020).

[4] "Ihktisar Hasil Pemeriksaan Semester dan II Tahun2016," Jakarta, 2016.

[5] A. Sanchez-Graells, "Procurement in the Time of COVID-19," SSRN Electron. J., pp. 1-10, 2020, doi: 10.2139/ssrn.3570154.

[6] Redaksi Kumparan, "Melihat Kembali Kasus Korupsi Alkes yang Menjerat Eks Menkes Siti Fadilah," Kumparan.com, 2020.

https://kumparan.com/kumparannews/mel ihat-kembali-kasus-korupsi-alkes-yangmenjerat-eks-menkes-siti-fadilah1tULmqYFQBE/full (diakses 16 September 2020) (accessed Sep. 16, 2020).

[7] P. . W. Kingori and D. K. Ngugi, "Determinant Of Procurement Performance At Retirement Benefit Authority In Kenya," Eur. J. Bus. Manag., vol. 1, no. 11, 2014.

[8] R. Kasisi, M. M. Benjamin, and G. H. Mwangi, "Factors Affecting the Performance of the Procurement Function in Government Organisations: A Case Study of National Oil Corporation of Kenya," Int. J. Sci. Eng. Res., vol. 3, no. 10, pp. 30-35, 2015.
[9] T. Aryati and L. Pangaribuan, "Analisis Pengaruh Implementasi E-Procurement Dan Kompetensi Pegawai Terhadap Kinerja Pengadaan," Penelit. Dan Karya Ilm., vol. 4, no. 1, p. 19, 2019, doi: 10.25105/pdk.v4i1.4012.

[10] L. Heriawati, "Pengaruh Penerapan Electronic Procurement dan Good Governance Terhadap Kinerja Pengadaan Barang dan Jasa Pada Bagian Pengadaan Barang dan Jasa Sekretariat Daerah Kab Pandeglang," Institut IImu Sosial dan Manajemen STIAMI, 2018

[11] Sugiyono, Metode Penelitian Bisnis (Pendekatan Kuantitatif, Kualitatif, dan $R \& D$. Bandung: Alfabeta, 2016.

[12] M. N. Amtiran, "Analisis Pengaruh Insentif dan Faktor Motivasi terhadap Kinerja Anggota Kelompok Kerja (POKJA) Unit Layanan Pengadaan Pemerintah Daerah Kabupaten Sumba Timur," Universitas Terbuka, 2015.

[13] Y. G. Sucahyo and Y. Ruldeviyani, Implementasi E-Procurement Sebagai Inovasi Pelayanan Publik. Jakarta: Lembaga Kebijakan Pengadaan Barang/Jasa Pemerintah, 2009.

[14] Wibowo, Manajemen Kinerja. Jakarta: Raja Grafindo Perkasa, 2007.

[15] R. Pamacheche, R. Chinomona, and T. Chuchu, "Management's Commitment, Education and Ethics on Organisational Entrepreneurship: The Case of South African Non-Profit Organisations," J. Econ. adn Behav. Stud., vol. 8, 2016.

[16] D. Ginanjar, "Analisis Faktor yang Memengaruhi Efektivitas Perencanaan Pengadaan," Politeknik Keuangan Negara STAN, 2017.

[17] M. Koren and R. Petö, "Business disruptions from social distancing," no. March, pp. 1-15, 2020, [Online]. Available: http://arxiv.org/abs/2003.13983.

[18] I. Ghozali, Aplikasi Analisis Multivariate dengan Program IBM SPSS 23. Semarang: Badan Penerbit Universitas Diponegoro, 2016. 
[19] V. Herlina, Panduan Praktis Mengelola Data Kuesioner Menggunakan SPSS. Jakarta: Elex Media Komputindo, 2019.

[20] I. Ghozali, Aplikasi Analisis Multivariate dengan Program IBM SPSS 21 Update PLS Regresi. Semarang: Badan Penerbit Universitas Diponegoro, 2013.

[21] L. Lie, "Penggunaan MRA dengan Spss untuk Menguji Pengaruh Variabel Moderating terhadap Hubungan antara Variabel Independen dan Variabel Dependen," J. Teknol. Inf. Din., vol. XIV, no. 2, pp. 90-97, 2009, [Online]. Available: https://www.unisbank.ac.id/ojs/index.php/f ti1/article/view/95/90.

[22] M. A. F. Al Weshah, "Transparency in Application of Scientific Principles and Rules in Government Procurement to Improve Effectiveness of Service and Cost Reduction in the Public Sector," Far East J. Psycology Bus., vol. 10, no. September 2013, 2013.

[23] A. D. Pello, "Hubungan Motivasi dengan Hasil Belajar Peserta Pendidikan dan Pelatihan Barang dan Jasa Pemerintah." Bogor, 2017, [Online]. Available: http://pkm.uika-

bogor.ac.id/index.php/PTP/article/view/95.

[24] C. Argyris and R. S. Kaplan, "Implementing New Knowledge: The Case of ActivityBased Costing," Account. Horizons, vol. 8, 1994.

[25] P. E. D. Love, P. R. Davis, D. J. Edwards, and D. Baccarini, "Uncertainty Avoidance: Public Sector Clients and Procurement Selection," Int. J. Public Sect. Manag., vol. 21, 2008.

[26] G. S. Darma, Optimalisasi Penggunaan Teknologi Informasi dan Kinerja Organisasi. Denpasar: Undiknas Press, 2006.

\section{Biografi Penulis}

\section{Syahirul Alim}

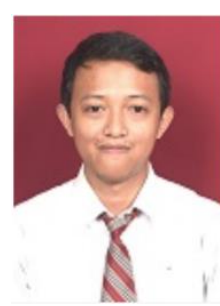

merupakan pegawai

Kementerian Keuangan yang bekerja pada Pusat Informasi dan Teknologi Keuangan, Sekretariat Jenderal Kementerian Keuangan. Alumni program D4 Akuntansi di Politeknik Keuangan Negara STAN pada tahun 2020. Sebelumnya lulus dari D3 Sekolah Tinggi Akuntansi Negara.

\section{Heru Akhmadi}

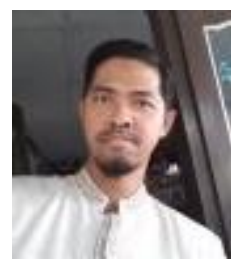

Dosen pada Program Studi Diploma III Kebendaharaan Negara, Politeknik Keuangan Negara STAN. Pendidikan terakhir Magister Informatika Institut Teknologi Bandung tahun 2008. Kompetensi penelitian pada bidang pelaksanaan anggaran, manajemen likuiditas, pembiayaan, investasi dan resiko keuangan negara. 